\title{
РОЛЬ МАССМЕДИА В ПОПУЛЯРИЗАЦИИ ОБРАЗА МАТЕРИНСТВА И СЕМЕЙНЫХ ЦЕННОСТЕЙ КАК НАЦИОНАЛЬНОЙ ИДЕИ РОССИЯН ${ }^{1}$
}

\section{THE ROLE OF MASS MEDIA IN POPULARIZATION THE IMAGE OF MOTHERHOOD AND FAMILY VALUES AS A NATIONAL IDEA OF THE RUSSIANS \\ I. Tkachenko \\ L. Lisitskaya}

Summary: The article highlights the relevance of the problem of forming the image of motherhood and the definition of the concept of the family as the basis not only of the moral foundations of society, but also of the spiritual unity of the nation. Since there is a problem of reducing the value of motherhood in Russia, the sources of its solution, according to the authors of the article, should be social institutions, the family itself, which forms the image of the mother and determines family values, but to a greater extent modern mass media, which have great opportunities to influence the minds and views of modern youth.

Keywords: motherhood, family, values, morality, morality, ethics, modern mass media, media production, image of media personalities.
$\mathrm{M}$ ы живем уже практически в эру пятой информационной революции, которая невероятным образом ускорила обмен информацией не только в межличностной коммуникации, но и в межэтнической. Большую роль в расширении информационного поля, несомненно, играют современные массмедиа как традиционные, так и новейшие. К последним мы относим развивающуюся на наших глазах интернет-журналистику и её разнообразную в жанровом и контенте-аксиологическом исполнении медиапродукцию, начиная от уже привычных постов в социальных сетях и заканчивая мультимедийными текстами, такими, например, как лонгрид - новый способ представления результатов работы журналиста. Специфической особенностью данной подачи текста является активное использование визуализации, а именно: фотографий, видео, инфографики и прочих мультимедийных элементов, которые вкрапливаются в канву текста и делают его восприятие более доступным, интересным, понятным.

Современная медиасфера является пока ещё недо-
Ткаченко Ирина Валериевна

Д.nсх.н., профессор, Армавирский государственный педагогический университет, г. Армавир

tkachenkoiv@mail.ru

Лисицкая Лариса Григорьевна

Д.филол.н., профессор, Армавирский государственный педагогический университет, г. Армавир

lislarisa14@mail.ru

Аннотация: В статье обозначена актуальность проблемы формирования образа материнства и определение концепта семьи как основы не только нравственных устоев социума, но духовного единства нации. К сожалению, в настоящее время в нашей стране меняется отношение к материнству в сторону снижения, в связи с чем, истоками решения этой проблемы, по мнению авторов статьи, должны стать социальные институты, сама семья, формирующая образ матери и определяющая семейные ценности, но в большей мере современные массмедиа, имеющие огромные возможности для влияния на умы и взгляды современной молодежи.

Ключевые слова: материнство, семья, ценности, нравственность, мораль, этика, современные массмедиа, медиапродукция, образ медийных личностей.

статочно изученной в аспекте её влияния на распространение в обществе моральных и этических ценностей, многие из которых формируют национальную идею россиян. Однако «анализ ценностных предпочтений открывает широкие возможности для исследования национального языкового сознания, построения модели языковой личности, для формирования носителя языка, принадлежащего определенному социокультурному сообществу с определенной моралью, поведением, отношением к людям» [2, с.8]. Одним из ценностных предпочтений является образ материнства и концепт семьи как основы не только нравственных устоев социума, но духовного единства нации.

Современное мировосприятие изменилось: на первый план выдвинулись проблемы в области политики и экономики, достаточно посмотреть количество политических и экономических телевизионных ток-шоу, рекламы, решающей коммерческие вопросы, но все эти проблемы будут решаться более успешно, более эффективно, если будут опираться на нравственность, мораль,

1 Исследование выполнено при финансовой поддержке Кубанского научного фонда в рамках научного проекта № ФНИ-ГО-20.1/26 
этику. К важной государственной проблеме нужно отнести и снижение демографии, к решению которой важно привлечь массмедиа и журналистов, особенно тех, кто работает в интернет-СМИ и по своему профессиональному долгу призван к распространению и пропаганде таких ценностных ориентиров, которые способны формировать его мировоззрение, поведенческие мотивы, жизненные идеалы.

Уместно вспомнить слова известного литературоведа и философа Михаила Эпштейна, который по-новому охарактеризовал стереоэтику с позиции современного человека, представление о которой полезно для журналиста, творца, созидателя, потому что, «развертываясь в размытости ценностного поля, стереоэтика вводит принцип совмещения разных нравственных перспектив, подобно тому, как зрение совмещает две разные проекции предмета и только поэтому воспринимает мир объемно, рельефно. Стереоэтика - нравственная зрячесть, обусловленная совмещением двух разных знаковых моральных проекций одного поступка» [10, с.750].

Позиция журналиста не однозначна: он человек, профессия которого призвана творить культуру, формулировать моральные принципы, ценностные ориентиры и нести эту массу в народ. Эту особенность можно отнести и к другим профессиям, таким, как учитель, воспитатель, но профессия журналиста - публичная, более ответственная и более влиятельная, поэтому понимание своего предназначения, особенно в эпоху доступного и мгновенно передающего любую информацию Интернета, очень важно. Журналист, создатель и проводник медиакультуры, несёт ответственность за контентно-аксиологическое взаимовоздействие в своих произведениях, за свою деятельность и речевое поведение перед обществом и своей совестью.

Этический аспект в деятельности журналиста строится не только на профессиональных, но и общечеловеческих ценностях, пропаганда которых - дело чести каждого медиатворца. Важно, чтобы, проповедуя эти ценности, журналист стремился приобщать миллионы людей к общепризнанным образцам и нормам высокой культуры и нравственности.

К приоритетам нравственности, несомненно, относится образ материнства и концепт семейных ценностей.

Демократизация духовной жизни в постсоветскую эпоху привела к двойственному отношению к институту материнства. С одной стороны, всегда приветствовалось большое количество детей в семье, было даже почетное звание «Мать-героиня», государство заботилось и продолжает заботиться о таких семьях. С другой стороны, родители, имеющие определенный жизненный опыт, нацеливают своих девочек на получение хорошего об- разования для успешной карьеры в будущем, для достижения материальной независимости, для получения профессии, которая удовлетворит запросы, моральные и материальные. К тому же, бытует мнение, что девушка, полностью посвятившая себя семье, детям, просто не смогла реализовать себя в профессии или вообще не определилась с выбором профессии, она воспринимается часто обществом как не стремящаяся к самореализации, к профессиональному успеху, к карьерному росту. Если еще некоторое время назад такое мнение было недостаточно распространенным, то сейчас, в эпоху демократизации, расширения различных возможностей, оно укрепилось и расширилось. Современные девушки мечтают о профессии, которая обеспечит карьерный рост, реализует амбициозные планы, даст материальный достаток, который позволит создать и обеспечить семью и детей. В связи с этим возникает другая проблема: успешные бизнес-леди, обретшие полную финансовую независимость, часто не могут найти кандидатуру в мужья, соответствующую их завышенным требованиям, и остаются одинокими. У них возникает желание стать матерью, даже при отсутствии мужа, современная медицина им может помочь. Все же достаточно зрелый для материнства возраст может стать помехой для деторождения в силу различных, в том числе физиологических причин.

Силуэтно обозначенные проблемы, связанные с необходимостью повышения статуса матери, материнства, сегодня стоят достаточно остро и выпукло. Их решение зависит от многих социальных институтов, от позиции общественности, на мнение которой могут повлиять журналисты, анализирующие данные вопросы, раскрывающие их суть через показ семей, матерей, пример которых важен для подражания. Важны различные журналистские материалы, разъясняющие и описывающие данную проблематику с позиций пропаганды здорового образа жизни и духовно-нравственных основ миссии женщины в современном обществе. Пока мы силу, разрушающие мир семьи и материнства, например, очень быстро распространяющаяся субкультура чайлдфри (от англ. child free - свободный от детей), которая пропагандирует желание не иметь детей. Это новое, особенно для нашей страны, направление, но охватывающее все больше и больше юношей и девушек, о чем свидетельствуют социальные сети. Например, «Вконтакте» на сегодняшний день насчитывается более сотни групп с данной тематикой, что объединяет тысячи людей по всей России. Другой пример, современная мода, декларирующая искусственную бедность в виде дырявой одежды, бесформенность, серость, половая размытость, что не вызывает положительно заряженных эмоций, желания нравиться, что в конечном итоге приводит к семейственности и материнству. Это в определенной мере объясняет статистические данные об увеличении детей-сирот, рождение которых было незапланированным, нежелательным, а поведение родителей, отказавшихся от своих 
детей или лишенных родительских прав, характеризуете безответственным, аморальным, даже приступным. Современные массмедиа постоянно информируют нас о таких родителях, о семьях, где жестоко обращаются с детьми, где не только бьют детей, но и оставляют в опасности, без присмотра, что приводит к печальным последствиям. Нужно отметить факт наличия подобных материалов в массмедиа, можно сказать, что подобные факты анализируются общественностью, осуждаются, ими занимаются правоохранительные органы, но всего этого недостаточно, требуются более активные и кардинальные меры, совершенно новые подходы к решению данной проблемы. С одной стороны, нужны жесткие подходы к горе-матерям, бросающим своих детей, но, с другой стороны, необходимо формировать у современных девушек материнские инстинкты, ценности, связанные с семьей, материнством, учить любить детей, радоваться их появлению, формировать желание воспитывать детей и гордиться их достижениями.

Многие ученые отмечают важность и необходимость изучения феномена материнства, но нужно констатировать, что данная область знаний недостаточно изучена и нуждается во всестороннем и тщательном исследовании с точки зрения психологических и морально-нравственных аспектов.

Феномен материнства как отдельное направление исследований был подвергнут анализу в естественных науках: медицине, физиологии, биологии. Позднее стало понятно, что для более полного представления о данной области знания нужны сведения из психологии, социологии и педагогики, только совместное изучение материнства может наметить пути решения уже обозначенных нами проблем.

Среди психологов, которые посвятили свои труды изучению данного вопроса, следует отметить работы Г. Г. Филипповой, так как в результате ее научных изысканий на рубеже веков в отечественной психологии возникло научное направление - «психология материнства». В рамках данного направления концепт «материнства» трактуется как «самостоятельная психологическая реальность, принадлежащая матери как субъекту» $[9$, с.8]. Важно, чтобы современные журналисты-аналитики были вооружены современными концепциями «материнства» и могли аргументировать свои выводы авторитетными научными тезисами.

Повышение интереса к проблеме материнства объясняется ещё и тем, что наметилась устойчивая тенденция к постепенной утрате традиционных ценностных ориентиров, к которым, в первую очередь, относится институт материнства.
Угасание интереса к материнству - проблема глобального масштаба, т.к. она наблюдается не только в России, но и во всем мире. Учеными определены некоторые причины данного положения: пример неудачного опыта своих родителей, воспитание в неполной семье, негативное отношение к материнству со стороны некоторой части общества, особенно молодых его представителей, материальные трудности, общественное принятие различных внебрачных форм взаимоотношений (например, гражданский брак). Перечисленные факторы не способствуют формированию ценностных представлений о материнстве.

Важно отметить, что сама семья сегодня не берет на себя, в силу разных причин, в том числе и перечисленных, функцию правильного примера, образца воспитания будущей матери. Следовательно, эти функциональные обязанности перекладываются на общественные институты, начиная с дошкольных организаций, школ и завершая социальными сетями, где ведущую роль должны сыграть журналисты со своими отвечающими требованиям необходимости сохранения традиционной семьи и формирования ценностных представлений о материнстве текстами. Мастера пера, а сейчас и клавиатуры должны на высоком профессиональном уровне, предполагающем ненавязчивость, деликатность, искусность, возрождать ценности материнства и отцовства, укреплять нравственность и мораль в молодёжной среде и популяризировать многодетную семью.

Именно современным массмедиа предстоит серьезная творческая деятельность для создания высококачественных произведений, пропагандирующих радость материнства и непреходящие семейные ценности. И всетаки, отмечая огромную роль СМИ, необходимо усилить и на государственном уровне пропаганду ценностей материнства. При этом весьма эффективным было бы привлечение образов медийных личностей, делая акцент на их семейственности, так как часто молодые люди выбирают примеры для подражания именно в этой среде, тогда образы семейных медийных личностей будут способствовать популяризации и распространению семейных ценностей.

Материнство не является врождённой потребностью и ценностью, поэтому так важно культивировать и воспитывать её у молодежи. Мы обозначили актуальность проблематики и очертили основные её аспекты. Несмотря на, казалось бы, зримую актуальность проблемы материнства как одной из основных социальных ценностей, которая должна быть заложена биологически, на нее очень сильно влияют общественные нормы и ценности. Проблема утраты ценности материнства - это многоаспектная проблема, которая требует комплексного и вдумчивого подхода к ее решению. 


\section{ЛИТЕРАТУРА}

1. Комарова, К.Ю. Психолого-педагогическая деятельность по формированию ценностного отношения к материнству у учащейся молодёжи. // Семья и личность: проблемы взаимодействия, № 10,2018, с. 44-50.

2. Лисицкая, Л.Г. Ценностно-нормативные ориентиры современных медиатекстов. - Армавир: РИО АГПА, 2012. - $248 c$.

3. Лисицкая, Л.Г. Прагматическая адекватность медиатекста: взаимодействие контента и аксиологии: диссертация доктора филологических наук. - Краснодар, 2010. - 355 c.

4. Лисицкая, Л.Г. СМИ как основа духовного здоровья современного обществав сборнике: евразийская интеграция//материалы IV международной научнопрактической конференции. Армавирский государственный педагогический университет, 2016. С. 157-160.

5. Овчарова, Р.В. Психологический анализ особенностей формирования, осознанного родительства в молодой семье. // Вестник института семьи, № 1,2008, c. 45-50.

6. Ткаченко, И.В., Комарова, К.Ю. (2018) Влияние материнства на развитие личности и семейных ресурсов женщин. // Известия Южного федерального университета. Педагогические науки, № 7, 2018, с. 99-104.

7. Tkachenko, I.V., Komarova, K.Yu., Semenova, F.O., Lisitskaya, L.G., Evdokimova, E.V. The determinants of forming a valuable attitude to maternity among female students. In: ICPE 2019 - International Conference on Psychology and Education, "The European Proceedings of Social \& Behavioural Sciences EpSBS". [0nline]. Available at: https://www.futureacademy.org.uk/publication/EpSBS(assessed 12.09.2019). D0l: 10.15405/epsbs.2019.07.93

8. Ткаченко, И.В. Личностно-развивающий ресурс семьи: онтология и феноменология: диссертация доктора психологических наук. - Сочи, 2009. - 414 с.

9. Филиппова, Г.Г. Психология материнства: концептуальная модель: мнография. - М.: Институт молодежи, 1999. - $286 c$.

10. Эпштейн, М. Знак пробела: 0 будущем гуманитарных наук. - М.: Новое литературное обозрение, 2004. - 864c.

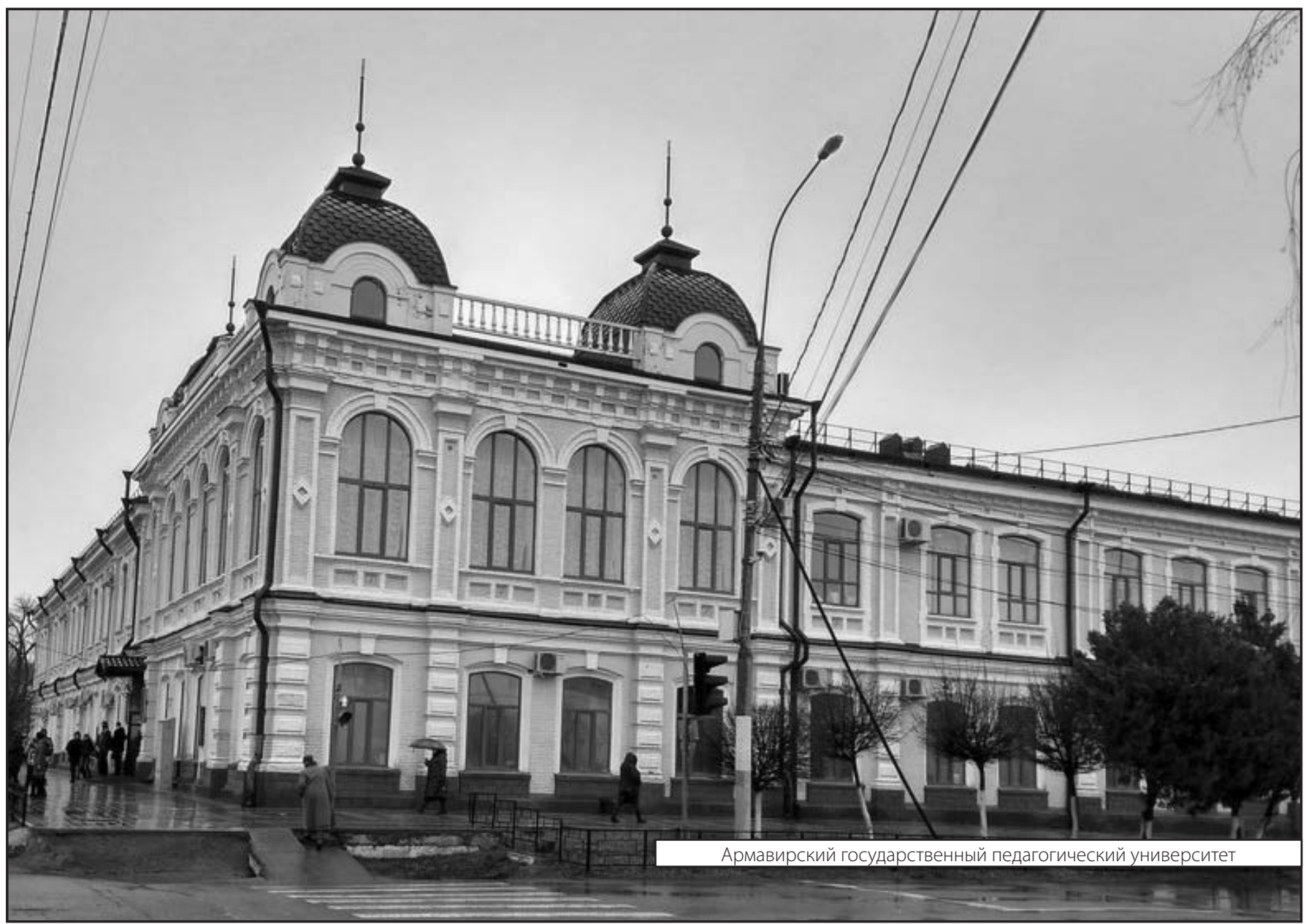

